\title{
Evaluation of the degradation and metabolic effects of the gut peptide xenin on insulin secretion, glycaemic control and satiety
}

\author{
Ashley I Taylor, Nigel Irwin, Aine M McKillop, Steven Patterson, Peter R Flatt and Victor A Gault \\ SAAD Centre for Pharmacy and Diabetes, School of Biomedical Sciences Research Institute, University of Ulster, Coleraine BT52 1SA, UK \\ (Correspondence should be addressed to N Irwin; Email: n.irwin@ulster.ac.uk)
}

\begin{abstract}
Recently, glucagon-like peptide 1 (GLP1) and glucosedependent insulinotropic polypeptide (GIP) have received much attention regarding possible roles in aetiology and treatment of type 2 diabetes. However, peptides co-secreted from the same enteroendocrine cells are less well studied. The present investigation was designed to characterise the in vitro and in vivo effects of xenin, a peptide co-secreted with GIP from intestinal K-cells. We examined the enzymatic stability, insulin-releasing activity and associated cAMP production capability of xenin in vitro. In addition, the effects of xenin on satiety, glucose homoeostasis and insulin secretion were examined in vivo. Xenin was time dependently degraded $\left(t_{1 / 2}=162 \pm 6 \mathrm{~min}\right)$ in plasma in vitro. In clonal BRIN-BD11 cells, xenin stimulated insulin secretion at $5.6 \mathrm{mM}(P<0.05)$ and $16.7 \mathrm{mM}(P<0.05$ to $P<0.001)$ glucose levels
\end{abstract}

compared to respective controls. Xenin also exerted an additive effect on GIP, GLP1 and neurotensin-mediated insulin secretion. In clonal $\beta$-cells, xenin did not stimulate cellular cAMP production, alter membrane potential or elevate intra-cellular $\mathrm{Ca}^{2+}$. In normal mice, xenin exhibited a short-acting $(P<0 \cdot 01)$ satiety effect at high dosage $(500 \mathrm{nmol} / \mathrm{kg})$. In overnight fasted mice, acute injection of xenin enhanced glucose-lowering and elevated insulin secretion when injected concomitantly or $30 \mathrm{~min}$ before glucose. These effects were not observed when xenin was administered $60 \mathrm{~min}$ before the glucose challenge, reflecting the short half-life of the native peptide in vivo. Overall, these data demonstrate that xenin may have significant metabolic effects on glucose control, which merit further study.

Journal of Endocrinology (2010) 207, 87-93

\section{Introduction}

Xenin was originally identified in human gastric mucosa as a mammalian equivalent to the amphibian octapeptide xenopsin, a peptide homologous in structure to neurotensin (Feurle et al. 1992). It is a naturally occurring 25 amino acid peptide secreted from intestinal $\mathrm{K}$ cells into the bloodstream in response to feeding (Anlauf et al. 2000). Early studies identified a contraction and relaxation effect of xenin in the jejunum, and a relaxation effect in the colon of guinea pigs (Feurle et al. 1996). Subsequent studies have shown xenin to elicit dose-dependent contractions in $\operatorname{dog}$ gall bladder and non-dose-dependent contractions in the jejunum (Kamiyama et al. 2007).

More recent advances in the understanding of xenin physiology have focused on anorectic and satiety actions, because of its discovery in the hypothalamus (Alexiou et al. 1998). Thus, a concentration-dependent inhibitory effect on food intake has since been demonstrated in chicks and rats (Cline et al. 2007, Nandar et al. 2008, Cooke et al. 2009). In addition, i.c.v. and i.p. xenin injection has been shown to reduce food intake in mice (Leckstrom et al. 2009). Similar to other anorectic gastrointestinal peptides, levels of circulating xenin appear to increase after a meal, suggesting that xenin may regulate food intake by acting as a satiety factor (Feurle et al. 2003). In addition, Cooke et al. (2009) demonstrated that i.c.v. administration of xenin reduced food intake in rats. Furthermore, the same study also reported that acute, but not chronic, peripheral administration of xenin reduced food intake in mice and rats (Cooke et al. 2009). Indeed, it has recently been shown that xenin reduces feeding in part by acting through signalling pathways in the hypothalamus, which are independent of those used by leptin or melanocortin (Leckstrom et al. 2009).

However, little is known about the physiological significance of xenin secretion and action. Xenin probably appeared early in evolution as its amino acid sequence is conserved from yeast to mammals (Hamscher et al. 1996). Despite this, its exact role in mammalian physiology remains elusive. Since xenin is structurally similar to neurotensin, it is thought to bind and activate the neurotensin receptor subtype 1 (Clemens et al. 1997). Interestingly, the feedingsuppressive effect of xenin is abolished in neurotensin receptor-deficient mice, thus supporting a role for this receptor in the anorectic effect of xenin (Kim \& Mizuno 2010). However, additional biological effects are apparent, but identification of a specific 'xenin receptor' is still outstanding. 
For example, in dogs, i.v. infusion of xenin stimulated exocrine pancreatic secretion and also evoked a rise in insulin and glucagon levels as well as an increase in vasoactive intestinal polypeptide and pancreatic polypepide levels (Feurle et al. 1997). Interestingly, a C-terminally truncated form of xenin, xenin-8, has been shown to exert possible insulinotropic and glucagonotropic actions in the perfused rat pancreas, but lacked somatostatin-releasing effects (Silvestre et al. 2003). Furthermore, given that plasma xenin concentrations were significantly elevated during feeding (Feurle et al. 2003), and that it is secreted from the same $K$ cell as the incretin hormone glucose-dependent insulinotropic polypeptide (GIP), the possibility of xenin functioning in an incretin-like context is also conceivable. Therefore, the present study has examined the plasma stability and satiety effects of xenin, and further characterised the glucoselowering and insulinotropic effects of xenin both alongside GIP, glucagon-like peptide-1 (GLP1) and neurotensin.

\section{Materials and Methods}

\section{Degradation of xenin in murine plasma}

Degradation profile of xenin was assessed in pooled plasma from fasted normal mice using HPLC analysis as described previously (Gault et al. 2002). Briefly, xenin (50 $\mathrm{g}$; GL Biochem Ltd, Shanghai, China) was incubated at $37^{\circ} \mathrm{C}$ in $50 \mathrm{mM}$ triethanolamine $-\mathrm{HCl}(\mathrm{pH} 7 \cdot 8)$ with mouse plasma $(50 \mu \mathrm{l})$ for $0,30,60,120,240$ and $360 \mathrm{~min}$. The incubation was repeated in the presence of the DDP IV inhibitor vildagliptin $(10 \mu \mathrm{M})$. This concentration has been shown in our laboratory to inhibit DPP IV-mediated degradation of GIP and GLP1. Reactions were terminated by the addition of $10 \%$ (v/v) trifluoroacetic acid/water. Intact xenin was separated from the major degradation products by HPLC and peaks collected manually before matrix-assisted laser desorption ionisation time-of-flight mass spectrometry (MALDI-TOF MS) analysis. HPLC peak area data were used to calculate percentage-intact peptide remaining at various time points throughout incubation.

\section{In vitro biological activity}

For cAMP measurements, BRIN-BD11 cells were collected, seeded into 96 -well plates $\left(3 \times 10^{4}\right.$ cells per well) and grown for $16 \mathrm{~h}$. Cells were washed twice in Hanks-buffered saline (HBS) buffer and incubated $\left(20 \mathrm{~min} ; 37^{\circ} \mathrm{C}\right)$ with varying concentrations of xenin $\left(10^{-12}-10^{-6} \mathrm{M}\right)$ in HBS buffer containing $1 \mathrm{mM}$ 3-isobutyl-1-methylxanthine in the presence of 5.6 or $16.7 \mathrm{mM}$ glucose. Medium was subsequently removed, cells were lysed and cAMP levels in the lysate were measured using an HTS chemiluminescent immunoassay kit (Millipore, Watford, UK).

For the assessment of insulin release, BRIN-BD11 cells were seeded into 24 -well plates $\left(10^{5}\right.$ cells per well) and allowed to attach overnight at $37^{\circ} \mathrm{C}$. The original characteristics of these cells have been reported previously (McClenaghan et al. 1996). Before acute tests, cells were pre-incubated (40 min; $37^{\circ} \mathrm{C}$ ) in Krebs-Ringer bicarbonate buffer (KRBB) ( $\left.\mathrm{pH} 7 \cdot 4\right)$ supplemented with $0.5 \%(\mathrm{w} / \mathrm{v})$ BSA and $1.1 \mathrm{mM}$ glucose. Test incubations were performed in the presence of 5.6 or $16.7 \mathrm{mM}$ glucose with a range of concentrations of xenin alone or in the presence of native GIP, GLP1 or neurotensin $\left(10^{-8} \mathrm{M}\right)$. After incubation $\left(20 \mathrm{~min} ; 37^{\circ} \mathrm{C}\right)$, buffer was removed from each well and aliquots $(200 \mu \mathrm{l})$ were stored at $-20{ }^{\circ} \mathrm{C}$ before measurement of insulin.

For measurement of membrane potential and intra-cellular $\left[\mathrm{Ca}^{2+}\right]\left(\left[\mathrm{Ca}^{2+}\right]_{\mathrm{i}}\right)$, BRIN-BD11 cells were utilised as described previously (McClenaghan et al. 2009). Briefly, cells were seeded into 96-well blackwalled clear-bottom microplates at a density of $1 \cdot 0 \times 10^{5}$ cells/well and allowed to attach overnight before replacing the culture medium with either standard culture medium or culture medium supplemented with various concentrations of xenin in the presence of 5.6 or $16.7 \mathrm{mM}$ glucose. After culture for $18 \mathrm{~h}$, the medium was replaced with $100 \mu \mathrm{l}$ of KRBB and monolayers were incubated for $20 \mathrm{~min}$, after which $100 \mu \mathrm{l}$ of either Flex membrane potential assay kit reagent (McClenaghan et al. 2009) or Flex calcium assay kit reagent (Molecular Devices, Sunnyvale, CA) were added to the wells at $37^{\circ} \mathrm{C}$ as described previously (McClenaghan et al. 2009). Fluorometric data were acquired using the FlexStation scanning fluorimeter and integrated fluid transfer workstation (Molecular Devices). The cells were exposed to excitation from a xenon-arc flash lamp at a wavelength of $530 \mathrm{~nm}$ (membrane) or $485 \mathrm{~nm}$ $\left(\left[\mathrm{Ca}^{2+}\right]_{\mathrm{i}}\right)$, and subsequent fluorescence emission was measured at $565 \mathrm{~nm}$ (membrane) or $525 \mathrm{~nm}\left(\left[\mathrm{Ca}^{2+}\right]_{\mathrm{i}}\right)$. Emission cut-off filters were set at $550 \mathrm{~nm}$ for membrane potential or $515 \mathrm{~nm}$ for $\left[\mathrm{Ca}^{2+}\right]_{\mathrm{i}}$.

\section{Animals}

Normal mice derived from the colony originally maintained at Aston University, UK (Flatt \& Bailey 1981), were used at 16-20 weeks of age. Animals were housed individually in an air-conditioned room at $22 \pm 2{ }^{\circ} \mathrm{C}$ with a $12 \mathrm{~h}$ light: $12 \mathrm{~h}$ darkness cycle. Drinking water and standard rodent maintenance diet (Trouw Nutrition, Cheshire, UK) were freely available. Groups of six to eight animals were used for individual tests. All animal experiments were carried out in accordance with the UK Animals (Scientific Procedures) Act 1986.

\section{In vivo studies}

For food intake studies, mice were fasted for $12 \mathrm{~h}$ before s.c. injection of 50, 100 or $500 \mathrm{nmol} / \mathrm{kg}$ xenin. Mice were then allowed free access to normal chow. Cumulative food intake was measured at the time points indicated in figure 3. For glucose-homoeostatic and insulin-releasing assessment of xenin, groups of overnight $(18 \mathrm{~h})$ fasted mice were injected 
s.c. with glucose alone $(18 \mathrm{nmol} / \mathrm{kg})$ or in combination with xenin $(25 \mathrm{nmol} / \mathrm{kg})$. For duration of biological action studies, groups of mice were similarly injected with xenin $(25 \mathrm{nmol} / \mathrm{kg})$ or vehicle $(0.9 \% \mathrm{w} / \mathrm{v}, \mathrm{NaCl}) 30$ or $60 \mathrm{~min}$ before glucose load $(18 \mathrm{mmol} / \mathrm{kg})$.

\section{Biochemical analyses}

Blood samples were taken from the cut tip of the tail vein of conscious mice at times indicated in the figures. Blood glucose was measured directly using a hand-held Ascencia Contour blood glucose meter (Bayer Healthcare). For insulin analysis, blood samples were collected from the cut tip on the tail vein of conscious mice into chilled fluoride/heparin glucose microcentrifuge tubes (Sarstedt, Numbrecht, Germany). Plasma was separated immediately by centrifugation (30 s at $13000 \mathrm{~g}$ ) using a Beckman microcentrifuge (Beckman Instruments, Galway, Ireland) and stored at $-20{ }^{\circ} \mathrm{C}$ before insulin analysis. Insulin was determined using a modified dextran-coated charcoal RIA as described previously (Flatt \& Bailey 1981).

\section{Statistical analysis}

Data are expressed as mean \pm s.E.M., and values were compared using repeated-measures ANOVA or one-way ANOVA, followed by the Student-Newman-Keuls post hoc test, as appropriate. Area under the curve (AUC) analyses were calculated using the trapezoidal rule with baseline subtraction. $P<0 \cdot 05$ was considered to be statistically significant.

\section{Results}

Degradation of xenin by murine plasma and identification of products

Xenin was rapidly degraded by murine plasma over the $6 \mathrm{~h}$ period as determined by HPLC and MALDI-TOF analysis (Fig. 1A). Thus, native xenin was degraded by $7 \%$ at $30 \mathrm{~min}$, $14 \%$ at $60 \mathrm{~min}, 37 \%$ at $120 \mathrm{~min}, 72 \%$ at $240 \mathrm{~min}$ and $91 \%$ $(P<0.001)$ at $360 \mathrm{~min}$. The $t_{1 / 2}$ for xenin under these conditions was calculated to be $162 \pm 6 \mathrm{~min}$. Incubation of peptide without plasma did not produce a significant change in peptide peak area at any of the time points measured. Interestingly, incubation with the DPP IV inhibitor vildagliptin did not prevent xenin degradation (data not shown).

\section{In vitro actions of xenin}

Xenin induced a significant $(P<0 \cdot 05)$ augmentation of insulin release from BRIN-BD11 cells at concentrations of $10^{-6} \mathrm{M}$ and above in the presence of $5.6 \mathrm{mM}$ glucose (Fig. 1B). Moreover, the insulinotropic action of xenin was
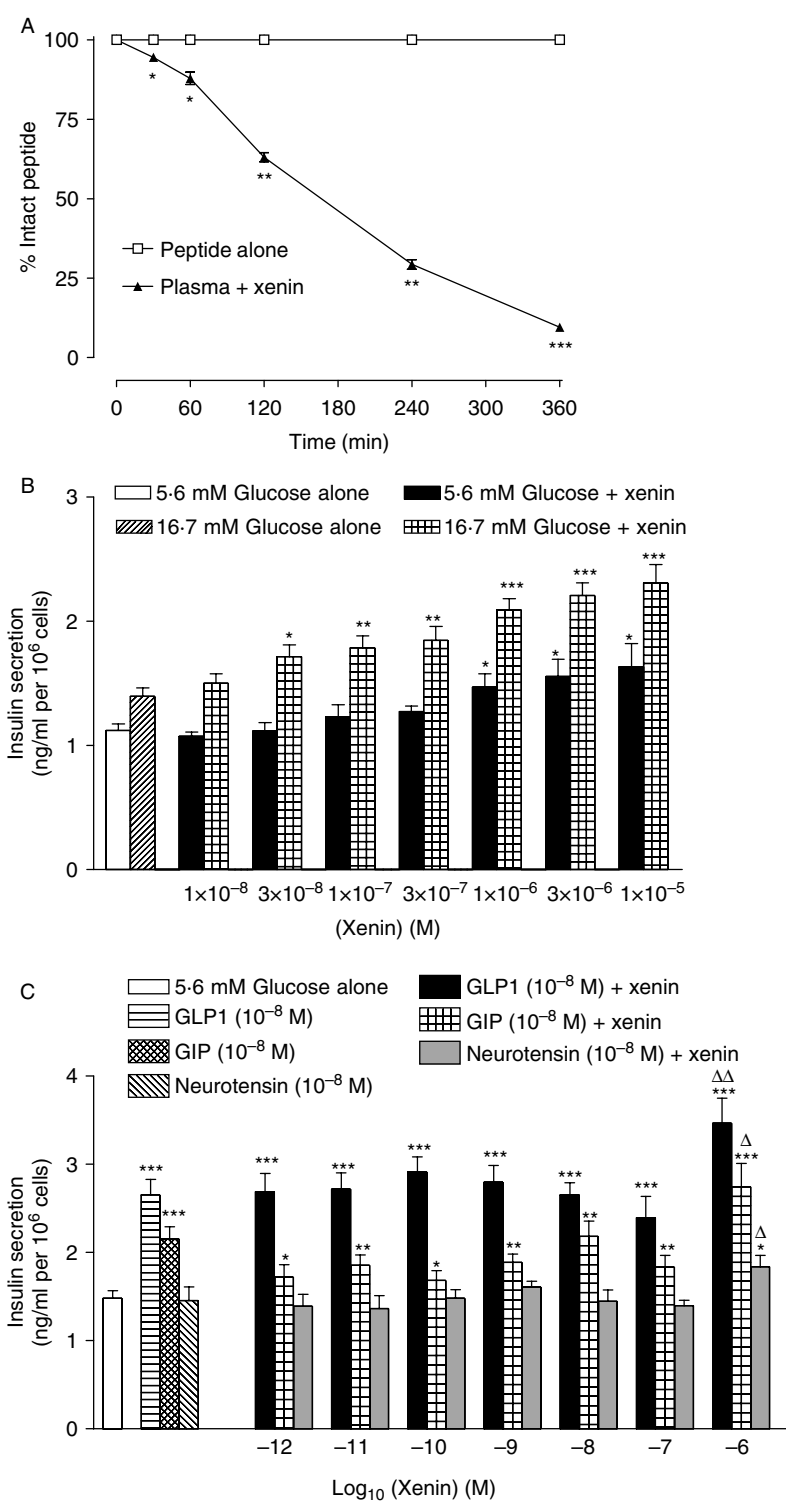

Figure 1 Plasma degradation profile of xenin and insulin secretory effects in BRIN-BD11 cells. (A) Resistance of xenin to degradation by plasma was measured $(n=3)$ after $0,30,60,120,240$ and $360 \mathrm{~min}$ incubations. Reaction products were subsequently analysed by HPLC and degradation expressed as a percentage of intact peptide relative to the major degradation fragments. (B) BRINBD11 cells were exposed to various concentrations of xenin at $5 \cdot 6$ and $16.7 \mathrm{mM}$ glucose concentrations for $20 \mathrm{~min}$ and insulin release measured using RIA. (C) BRIN-BD11 cells were incubated with a range of concentrations of xenin in the presence of stimulatory GIP, GLP1 or neurotensin $\left(10^{-8} \mathrm{M}\right)$ for $20 \mathrm{~min}$ and insulin release measured using RIA. Values represent means \pm s.E.M. ${ }^{*} P<0 \cdot 05$, $* * P<0.01$ and $* * * P<0.001$ compared with respective control. ${ }^{\Delta} P<0.05$ and ${ }^{\Delta \Delta} P<0.01$ compared with respective stimulatory effect of GIP, GLP1 or neurotensin. 

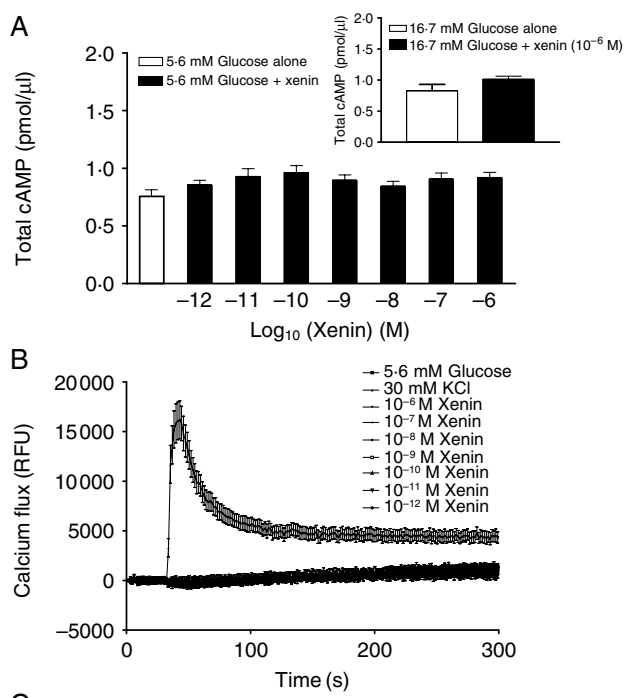

C
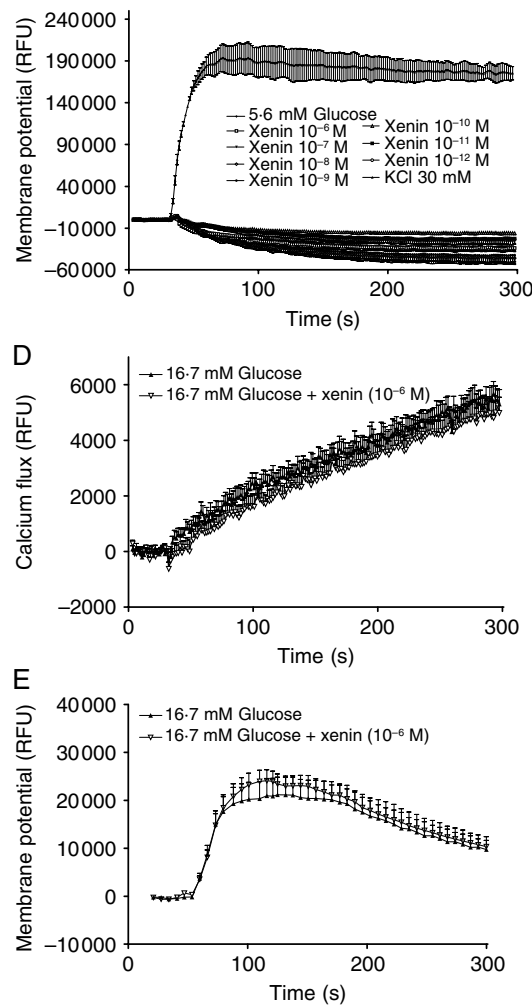

Figure 2 Effects of xenin on $\beta$-cell signalling pathways. (A) BRINBD11 cells were exposed to various concentrations of xenin at 5.6 and $16.7 \mathrm{mM}$ (inset) glucose for $20 \mathrm{~min}(n=4)$ and cAMP production subsequently measured using ELISA. (B and D) BRIN-BD11 cells were exposed to various concentrations of xenin at (B) $5.6 \mathrm{mM}$ and (D) $16.7 \mathrm{mM}$ glucose for $20 \mathrm{~min}(n=4)$, and membrane potential was measured using the FlexStation scanning fluorimeter. ( $C$ and $\mathrm{E}$ ) BRIN-BD11 cells were exposed to various concentrations of xenin at (C) $5.6 \mathrm{mM}$ and

(E) $16.7 \mathrm{mM}$ glucose for $20 \mathrm{~min}(n=4)$, and intra-cellular $\mathrm{Ca}^{2+}$ was measured using the FlexStation scanning fluorimeter.

Values represent means \pm s.E.M. significantly $(P<0.05$ to $P<0.001)$ superior at $16.7 \mathrm{mM}$ glucose, achieving significance at $3 \times 10^{-8} \mathrm{M}$ xenin. In addition, xenin $\left(10^{-6} \mathrm{M}\right)$ significantly $(P<0 \cdot 05$ to $P<0 \cdot 01)$ enhanced the insulinotropic response of GLP1, GIP and neurotensin (Fig. 1C). However, xenin did not stimulate the production of cAMP in BRIN-BD11 cells over the concentration range $\left(10^{-12}-10^{-6} \mathrm{M}\right)$ tested (Fig. 2A). In addition, xenin did not have any significant effect on membrane potential, $\left[\mathrm{Ca}^{2+}\right]_{i}$ or cAMP at 5.6 or $16.7 \mathrm{mM}$ glucose levels (Fig. 2A-E).

\section{Effects of xenin on feeding}

Xenin did not induce a significant change in cumulative food intake in overnight fasted mice when administered at a dose of 50 or $100 \mathrm{nmol} / \mathrm{kg}$ (Fig. 3). However, when mice received a dose of $500 \mathrm{nmol} / \mathrm{kg}$, xenin induced a $60 \%$ decrease $(P<0 \cdot 01)$ in food intake at $30 \mathrm{~min}$ post injection compared to controls (Fig. 3). This satiety effect was not evident at the later time points examined (Fig. 3).

Acute glucose-lowering and insulinotropic effects of xenin in normal mice

Administration of xenin to $18 \mathrm{~h}$ fasted mice in combination with glucose significantly $(P<0 \cdot 05$ to $P<0 \cdot 001)$ lowered individual and overall glucose levels in overnight fasted mice (Fig. 4A). This was associated with a significant $(P<0 \cdot 05)$ elevation of overall insulin release compared to controls (Fig. 5A).

Persistent glucose-lowering and insulinotropic effects of xenin in normal mice

Administration of xenin 30 min earlier significantly $(P<0 \cdot 05)$ decreased individual plasma glucose levels after s.c. glucose injection in mice (60 min post injection; Fig. 4B). This was associated with a decreased overall glycaemic excursion (Fig. 4B). The overall insulin release as assessed by AUC measures was significantly elevated in overnight fasted mice compared to respective controls (Fig. 5B). Administration of xenin $60 \mathrm{~min}$ before glucose challenge annulled the glucoselowering and insulin-releasing effects of xenin (Figs 4C and 5C).

\section{Discussion}

Since its discovery in 1992, xenin has received attention as an effecter of gut motility (Feurle et al. 1992, 2003). In addition, xenin is now thought to be involved in the regulation of calorie intake (Leckstrom et al. 2009) and possibly insulin secretion (Silvestre et al. 2003). Thus, the aim of the current study was to evaluate the effects and role of xenin in food intake, glucose homoeostasis and insulin secretion.

Initially, we undertook in vitro studies in BRIN-BD11 cells to confirm earlier reports that xenin-related peptides 
stimulate insulin release (Silvestre et al. 2003). To our knowledge, this is the first time that the in vitro insulinreleasing action of the full-length form of xenin (25 amino acids) has been assessed. We confirmed that xenin possesses strong insulin secretory actions under normoglycaemic and particularly hyperglycaemic conditions. The effects were more pronounced at higher glucose levels raising the possibility of glucose-dependent actions, akin to the effects of GIP and GLP1 (Green \& Flatt 2007). Nonetheless, it should be noted that in contrast to xenin, GLP1 induces changes in membrane electrical activity and intra-cellular $\mathrm{Ca}^{2+}$ concentrations at elevated glucose concentrations (Yada et al. 1993, Gromada et al. 1997, Fernandez \& Valdeolmillos 1999). However, this glucose-dependent increase in insulin secretion is comparable to the findings of Silvestre et al. (2003), where xenin-8 displayed similar effects in the perfused rat pancreas. Furthermore, we have shown an additive insulinotropic effect of xenin on GIP- and GLP1-mediated insulin secretion, suggesting possibly synergistic interactions with the incretin hormones.

Given that xenin-mediated effects are thought to stem, in part, from binding and activating the neurotensin receptor (Clemens et al. 1997) involving calcium-dependent potassium channels (Feurle et al. 1996), we thought it prudent to investigate the mechanism of xenin-induced insulin release observed. However, no significant changes in membrane potential or intra-cellular $\mathrm{Ca}^{2+}$ were observed even with the highest concentration of xenin $\left(10^{-6} \mathrm{M}\right)$ tested under normo- or hyperglycaemic conditions. This suggests that xenin does not elicit its insulinotropic actions through binding the neurotensin receptor; however, further studies are needed to confirm this. Furthermore, xenin was devoid of effects on cAMP production in BRIN-BD11 cells, implying that unlike the incretin hormones GIP and GLP1 (Green \& Flatt 2007), it does not utilise this second messenger pathway in mediating its insulin secretory response. Thus, clarification of the mechanism of xenin-induced insulin release is necessary, possibly focusing on effects mediated through action of phospolipase C. Possible activation of this alternative signal regulation pathway would be consistent with additive effects of xenin when combined with either GIP or GLP1. However, it has been shown earlier that xenin does not exert an additive effect on carbachol-induced insulin release (Silvestre et al. 2003). Thus, taken together, additional work is needed to clarify the direct and indirect actions of xenin on insulin release. Furthermore, it has already been shown that xenin has effects on exocrine pancreatic secretions (Nustede et al. 1999).

Consistent with earlier reports (Cline et al. 2007, Nandar et al. 2008, Cooke et al. 2009, Leckstrom et al. 2009), we were able to demonstrate a satiety effect of xenin in normal mice. The dose required to induce such effects was high $(500 \mathrm{nmol} / \mathrm{kg})$, but this is in agreement with others (Leckstrom et al. 2009). However, knowledge of normal physiological circulating concentrations of xenin is required to aid interpretation. The short duration of action of satiety effects is in agreement with our in vitro studies on enzymatic
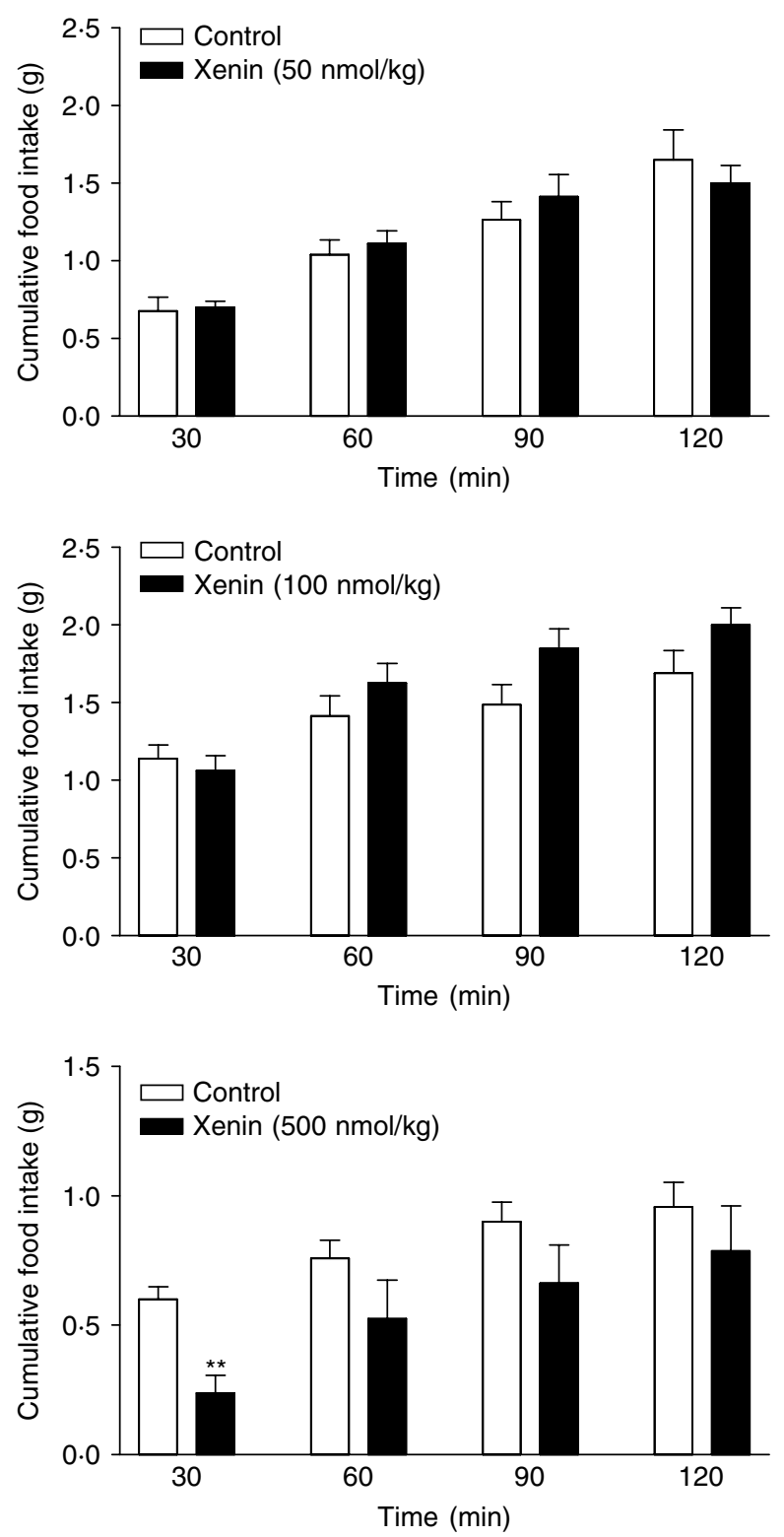

Figure 3 Effects of xenin on cumulative food intake in $12 \mathrm{~h}$ fasted normal mice. Cumulative food intake was measured after s.c. administration of $50 \mathrm{nmol} / \mathrm{kg}, 100 \mathrm{nmol} / \mathrm{kg}$ or $500 \mathrm{nmol} / \mathrm{kg}$ xenin. Values represent means \pm S.E.M. for eight mice. ${ }^{* *} P<0 \cdot 01$ compared to control.

stability, revealing xenin to be rapidly degraded to constituent metabolic fragments within $30 \mathrm{~min}$. To the authors' best knowledge, this is the first documentation of plasma-mediated xenin degradation. As such, the identity and biological activity of these degradation fragments require consideration and may reveal further insights into the physiological significance of xenin. However, it appears that unlike GIP and GLP1, DPP IV does not play a role in xenin degradation.

Given the in vitro insulinotropic effects of xenin in the current study, we evaluated the glucose-lowering and 

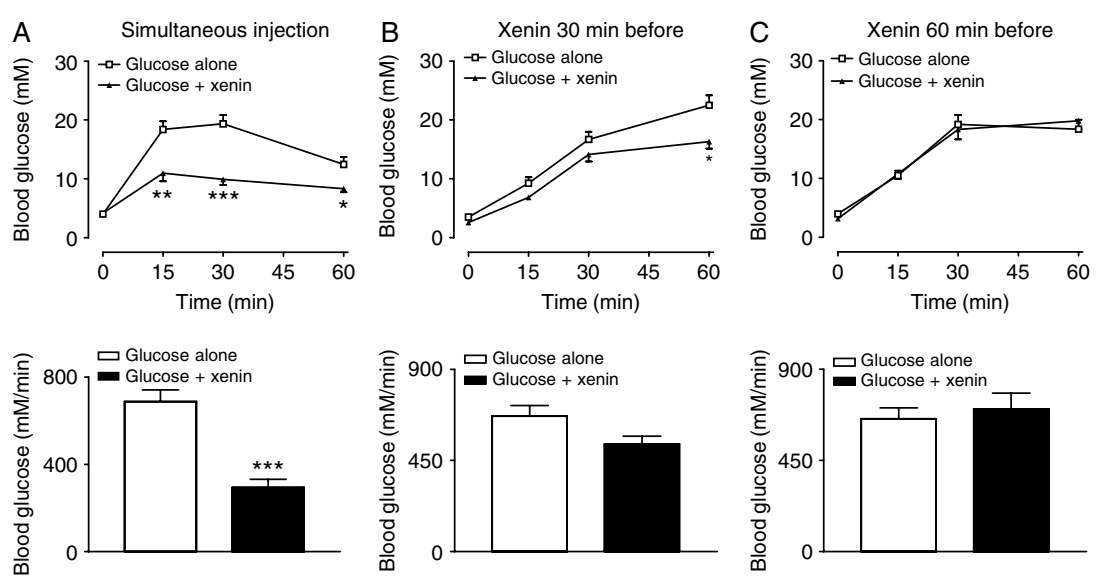

Figure 4 (A) Acute and (B and C) persistent glucose-lowering effects of xenin in $18 \mathrm{~h}$ fasted normal mice. (A) Blood glucose concentrations were measured before and after s.c. administration of glucose alone $(18 \mathrm{mmol} / \mathrm{kg})$ or in combination with xenin $(25 \mathrm{nmol} / \mathrm{kg})$. (B and C) Xenin ( $25 \mathrm{nmol} / \mathrm{kg}$ ) was administered (B) $30 \mathrm{~min}$ or (C) $60 \mathrm{~min}$ before glucose load $(18 \mathrm{mmol} / \mathrm{kg})$. Blood glucose area under the curve (AUC) values for 0-60 min post injection are also shown. Values represent means \pm S.E.M. for eight mice. ${ }^{*} P<0 \cdot 05,{ }^{* *} P<0 \cdot 01$ and $* * * P<0 \cdot 001$ compared to control.

insulin-releasing actions of a bolus injection of xenin in normal mice. Xenin administration was associated with lowered glycaemic and enhanced insulin levels during glucose tolerance tests. Furthermore, the effects were still evident when xenin was administered $30 \mathrm{~min}$ before glucose challenge. However, the short duration of biological action of native xenin was evidenced from the lack of biological effect when administered $60 \mathrm{~min}$ before glucose. Nonetheless, it is clear that in addition to the well documented effect of xenin on feeding, this peptide may also function as a gluco-regulatory hormone.
In conclusion, these data indicate that xenin is a shortacting peptide with potential important metabolic effects on blood glucose control. Further study of the biological effects of xenin in animal models of diabetes and or obesity will help to delineate any physiological or potential therapeutic role. In addition, investigation of the metabolic significance of xenin enzymatic degradation products is required. Generation of specific xenin antagonists or longer acting xenin mimetics may be useful in assessing the overall biological consequence of xenin-mediated actions.
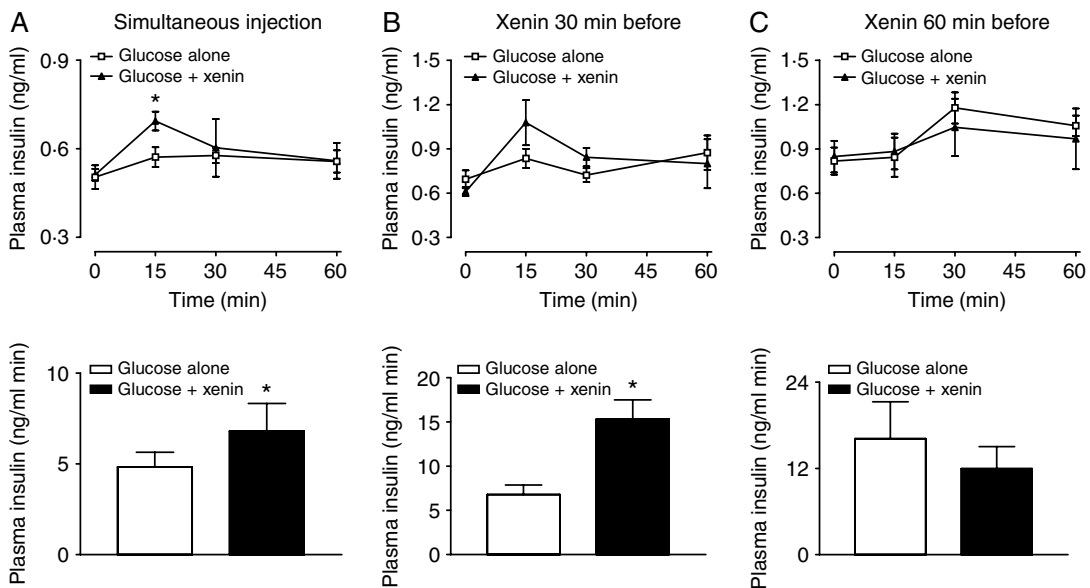

Figure 5 (A) Acute and (B and C) persistent insulin-releasing effects of xenin in $18 \mathrm{~h}$ fasted normal mice. (A) Plasma insulin concentrations were measured before and after s.c. administration of glucose alone $(18 \mathrm{mmol} / \mathrm{kg})$ or in combination with xenin $(25 \mathrm{nmol} / \mathrm{kg})$. (B and C) Xenin ( $25 \mathrm{nmol} / \mathrm{kg}$ ) was administered (B) $30 \mathrm{~min}$ or (C) $60 \mathrm{~min}$ before glucose load $(18 \mathrm{mmol} / \mathrm{kg})$. Plasma insulin area under the curve (AUC) values for 0-60 min post injection are also shown. Values represent means \pm s.E.M. for eight mice. $* P<0 \cdot 05$ compared to control. 


\section{Declaration of interest}

The authors declare that there is no conflict of interest that could be perceived as prejudicing the impartiality of the research reported.

\section{Funding}

This study was supported by the SAAD Trading and Contracting Company and the Department of Education and Learning, Northern Ireland.

\section{References}

Alexiou C, Zimmermann JP, Schick RR \& Schusdziarra V 1998 Xenin - a novel suppressor of food intake in rats. Brain Research 800 294-299. (doi:10. 1016/S0006-8993(98)00535-6)

Anlauf M, Weihe E, Hartschuh W, Hamscher G \& Feurle GE 2000 Localization of xenin-immunoreactive cells in the duodenal mucosa of humans and various mammals. Journal of Histochemistry and Cytochemistry 48 1617-1626.

Clemens A, Katsoulis S, Nustede R, Seebeck J, Seyfarth K, Morys-Wortmann C, Feurle GE, Fölsch UR \& Schmidt WE 1997 Relaxant effect of xenin on rat ileum is mediated by apamin-sensitive neurotensin-type receptors. American Journal of Physiology 272 G190-G196.

Cline MA, Nandar W \& Rogers JO 2007 Xenin reduces feed intake by activating the ventromedial hypothalamus and influences gastrointestinal transit rate in chicks. Behavioural Brain Research 179 28-32. (doi:10.1016/j. bbr.2007.01.008)

Cooke JH, Patterson M, Patel SR, Smith KL, Ghatei MA, Bloom SR \& Murphy KG 2009 Peripheral and central administration of xenin and neurotensin suppress food intake in rodents. Obesity 17 1135-1143. (doi:10. 1038/oby.2008.652)

Fernandez J \& Valdeolmillos M 1999 Glucose-dependent stimulatory effect of glucagon-like peptide 1(7-36) amide on the electrical activity of pancreatic beta-cells recorded in vivo. Diabetes 48 754-757. (doi:10.2337/diabetes. 48.4.754)

Feurle GE, Hamscher G, Kusiek R, Meyer HE \& Metzger JW 1992 Identification of xenin, a xenopsin-related peptide, in the human gastric mucosa and its effect on exocrine pancreatic secretion. Journal of Biological Chemistry 267 22305-22609.

Feurle GE, Klein A, Hamscher G, Metzger JW \& Schuurkes JA 1996 Neurokinetic and myokinetic effects of the peptide xenin on the motility of the small and large intestine of guinea pig. Journal of Pharmacology and Experimental Therapeutics 278 654-661.

Feurle GE, Ikonomu S, Partoulas G, Stoschus B \& Hamscher G 2003 Xenin plasma concentrations during modified sham feeding and during meals of different composition demonstrated by radioimmunoassay and chromatography. Regulatory Peptides 111 153-159. (doi:10.1016/S01670115(02)00281-1)

Feurle GE, Heger M, Niebergall-Roth E, Teyssen S, Fried M, Eberle C, Singer MV \& Hamscher G 1997 Gastroenteropancreatic effects of xenin in the dog. Journal of Peptide Research 49 324-330. (doi:10.1111/j.1399-3011. 1997.tb01132.x)

Flatt PR \& Bailey CJ 1981 Abnormal plasma glucose and insulin responses in heterozygous lean $(\mathrm{ob} /+$ ) mice. Diabetologia 20 573-577. (doi:10.1007/ BF00252768)

Gault VA, Flatt PR, Bailey CJ, Harriott P, Greer B, Mooney MH \& O'Harte FP 2002 Enhanced cAMP generation and insulin-releasing potency of two novel Tyr1-modified enzyme-resistant forms of glucose-dependent insulinotropic polypeptide is associated with significant antihyperglycaemic activity in spontaneous obesity-diabetes. Biochemical Journal 367 913-920. (doi:10.1042/BJ20020319)

Green BD \& Flatt PR 2007 Incretin hormone mimetics and analogues in diabetes therapeutics. Best Practice \& Research. Clinical Endocrinology \& Metabolism 21 497-516. (doi:10.1016/j.beem.2007.09.003)

Gromada J, Ding WG, Barg S, Renström E \& Rorsman P 1997 Multisite regulation of insulin secretion by cAMP-increasing agonists: evidence that glucagon-like peptide 1 and glucagon act via distinct receptors. Pflügers Archiv 434 515-524. (doi:10.1007/s004240050431)

Hamscher G, Meyer HE \& Feurle GE 1996 Identification of proxenin as a precursor of the peptide xenin with sequence homology to yeast and mammalian coat protein alpha. Peptides 17 889-893. (doi:10.1016/01969781(96)00150-7)

Kamiyama Y, Aihara R, Nakabayashi T, Mochiki E, Asao T \& Kuwano H 2007 The peptide hormone xenin induces gall bladder contractions in conscious dogs. Neurogastroenterology and Motility 19 233-240. (doi:10. 1111/j.1365-2982.2006.00881.x)

Kim ER \& Mizuno MT 2010 Role of neurotensin receptor 1 in the regulation of food intake by neuromedins and neuromedin-related peptides. Neuroscience Letters 468 64-67. (doi:10.1016/j.neulet. 2009.10.064)

Leckstrom A, Kim ER, Wong D \& Mizuno TM 2009 Xenin, a gastrointestinal peptide, regulates feeding independent of the melanocortin signaling pathway. Diabetes 58 87-94. (doi:10.2337/db08-0260)

McClenaghan NH, Barnett CR, Ah-Sing E, Abdel-Wahab YH, O'Harte FP, Yoon TW, Swanston-Flatt SK \& Flatt PR 1996 Characterization of a novel glucose-responsive insulin-secreting cell line, BRIN-BD11, produced by electrofusion. Diabetes 45 1132-1140. (doi:10.2337/diabetes.45.8.1132)

McClenaghan NH, Scullion SM, Mion B, Hewage C, Malthouse JP, Flatt PR, Newsholme P \& Brennan L 2009 Prolonged L-alanine exposure induces changes in metabolism, $\mathrm{Ca}^{2+}$ handling and desensitization of insulin secretion in clonal pancreatic beta-cells. Clinical Science 116 341-351. (doi:10.1042/CS20080138)

Nandar W, Milligan JM \& Cline MA 2008 Mechanisms of xenin-induced anorectic response in chicks (Gallus gallus). General and Comparative Endocrinology 157 58-62. (doi:10.1016/j.ygcen.2008.03.012)

Nustede R, Schmidt WE, Horstmann O, Sikovec N, Schemminger R \& Becker H 1999 On the effect of xenin and xenin fragments on exocrine pancreas secretion in vivo. Regulatory Peptides 81 61-66. (doi:10.1016/ S0167-0115(99)00019-1)

Silvestre RA, Rodríguez-Gallardo J, Egido EM, Hernández R \& Marco J 2003 Stimulatory effect of xenin-8 on insulin and glucagon secretion in the perfused rat pancreas. Regulatory Peptides 115 25-29. (doi:10.1016/S01670115(03)00147-2)

Yada T, Itoh K \& Nakata M 1993 Glucagon-like peptide-1-(7-36)amide and a rise in cyclic adenosine $3^{\prime}, 5^{\prime}$-monophosphate increase cytosolic free $\mathrm{Ca}^{2+}$ in rat pancreatic beta-cells by enhancing $\mathrm{Ca}^{2+}$ channel activity. Endocrinology 133 1685-1692. (doi:10.1210/en.133.4.1685)

Received in final form 9 July 2010

Accepted 14 July 2010

Made available online as an Accepted Preprint

14 July 2010 